ARTICLE

https://doi.org/10.1038/s41467-019-08517-2

\title{
Stable salts of the hexacarbonyl chromium(I) cation and its pentacarbonyl-nitrosyl chromium(I) analogue
}

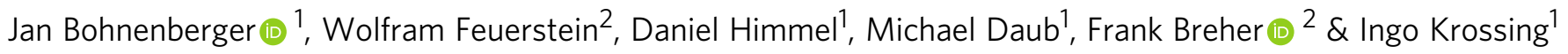

Homoleptic carbonyl radical cations are a textbook family of complexes hitherto unknown in the condensed phase, leaving their properties and applications fundamentally unexplored. Here we report on two stable 17-electron $\left[\mathrm{Cr}(\mathrm{CO})_{6}\right]^{*+}$ salts that were synthesized by oxidation of $\mathrm{Cr}(\mathrm{CO})_{6}$ with $\left.[\mathrm{NO}]^{+}\left[\mathrm{Al}\left(\mathrm{OR}^{\mathrm{F}}\right)_{4}\right]^{-}\left(\mathrm{R}^{\mathrm{F}}=\mathrm{C}\left(\mathrm{CF}_{3}\right)_{3}\right)\right)$ in $\mathrm{CH}_{2} \mathrm{Cl}_{2}$ and with removal of $\mathrm{NO}$ gas. Longer reaction times led to $\mathrm{NO} / \mathrm{CO}$ ligand exchange and formation of the thermodynamically more stable 18 -electron species $\left[\mathrm{Cr}(\mathrm{CO})_{5}(\mathrm{NO})\right]^{+}$, which belongs to the family of heteroleptic chromium carbonyl/nitrosyl cations. All salts were fully characterized (IR, Raman, EPR, NMR, scXRD, pXRD, magnetics) and are stable at room temperature under inert conditions over months. The facile synthesis of these species enables the thorough investigation of their properties and applications to a broad scientific community.

\footnotetext{
${ }^{1}$ Institut für Anorganische und Analytische Chemie and Freiburger Materialforschungszentrum (FMF), Universität Freiburg, Albertstr. 21, 79104 Freiburg, Germany. ${ }^{2}$ Karlsruhe Institute of Technology (KIT), Division Molecular Chemistry, Institute of Inorganic Chemistry, Engesserstr. 15, 76131 Karlsruhe, Germany. Correspondence and requests for materials should be addressed to F.B. (email: breher@kit.edu) or to I.K. (email: krossing@uni-freiburg.de)
} 
C arbon monoxide is amongst the most important ligands in transition metal chemistry. Thus, carbonyl complexes have been continuously and extensively studied over the past 130 years after the discovery of the first homoleptic carbonyl complex $\mathrm{Ni}(\mathrm{CO})_{4}$ by Mond in $1890^{1}$. Their beauty lies in their simplicity and their rich substitution and redox chemistry, which leads to a wide range of applications, spanning from catalysis to biochemistry and medicine ${ }^{2-7}$. Most condensed phase homoleptic transition metal carbonyl complexes and all neutral mononuclear homoleptic transition metal carbonyl complexes in particular, obey the 18 -electron rule ${ }^{7}$; the only exception is $\mathrm{V}(\mathrm{CO})_{6}$ as a 17 valence electron (VE) species. Neutral complexes can be reduced to gain anionic carbonyl metallates, such as $\left[\mathrm{V}(\mathrm{CO})_{6}\right]^{-}$, $\left[\mathrm{Fe}(\mathrm{CO})_{4}\right]^{2-}$ (discovered as early as 1930 ) or even clustered radical anions such as $\left[\mathrm{Fe}_{3}(\mathrm{CO})_{11}\right]^{\bullet-8,9}$. Transition metal carbonyl cations (TMCCs), however, could not be accessed until about 1960 , when the octahedral carbonyl cation $\left[\mathrm{Mn}(\mathrm{CO})_{6}\right]^{+}$was discovered ${ }^{10}$. Since the 1990 s, mainly superacidic media enabled the synthesis, isolation, and characterization of several homoleptic TMCCs, such as $\left[\mathrm{Au}(\mathrm{CO})_{2}\right]^{+11-13},\left[\mathrm{Fe}(\mathrm{CO})_{6}\right]^{2+14}$, $[\mathrm{Co}$ $\left.(\mathrm{CO})_{5}\right]^{+15}$ or even superelectrophilic $\left[\mathrm{Pd}(\mathrm{CO})_{4}\right]^{2+16}$, or $\left[\operatorname{Ir}(\mathrm{CO})_{6}\right]^{3+17}$. Despite the fact that all these complexes were prepared by an oxidative approach, all of them feature an even number of electrons. No open-shell TMCC with mononuclear metalloradical configuration ${ }^{18}$ has been synthesized and structurally characterized to date (cf. Table 1$)^{19-29}$. Typically, those would evade the open-shell situation by forming metal-metalbonded dimers, like seen for the reliably on spectroscopic data assigned dimeric platinum carbonyl cation $\left[(\mathrm{OC})_{3} \mathrm{Pt}-\mathrm{Pt}(\mathrm{CO})_{3}\right]^{2+23}$.

However, the chromium hexacarbonyl cation, as a prototype example for such open-shell TMCC systems, was the subject of several electrochemical investigations ${ }^{30-33}$, as well as gas phase and theoretical studies ${ }^{34-36}$. In principle, these rather weakly bound TMCCs should be ideal starting materials for further substitution chemistry. Yet, the established routes to TMCCs via superacidic media require specialized equipment/laboratories and superacids are often incompatible with commonly used ligands. This combination limited hitherto the possibilities for follow-up chemistry. Quite contrary, the approach delineated here uses the weakly coordinating anions (WCAs) $\left[\mathrm{Al}\left(\mathrm{OR}^{\mathrm{F}}\right)_{4}\right]^{-}$and $\left.\left[\mathrm{F}-\left\{\mathrm{Al}\left(\mathrm{OR}^{\mathrm{F}}\right)_{3}\right\}_{2}\right]^{-}\left(\mathrm{R}^{\mathrm{F}}=\mathrm{C}\left(\mathrm{CF}_{3}\right)_{3}\right)\right)$ that allow the use of regular organic solvents, as well as standard laboratory equipment. In combination, this approach facilitates synthesis of the target TMCC salts-if desired, also in multigram-scale-and enables a rich follow-up chemistry.

\section{Results and Discussion}

Synthesis. A suitable oxidant (strong and innocent) is required to prepare the target salts $\left[\mathrm{Cr}(\mathrm{CO})_{6}\right]^{\bullet+}[\mathrm{WCA}]^{-}$. Whilst $\mathrm{Ag}^{+}\left(E^{\circ}=\right.$ $+0.65 \mathrm{~V}$ vs. $\mathrm{Fc} / \mathrm{Fc}^{+}$in $\left.\mathrm{CH}_{2} \mathrm{Cl}_{2}\right)^{37}$ deelectronates $\left[\mathrm{Co}_{2}(\mathrm{CO})_{8}\right]$ in
$\mathrm{CO}$ atmosphere generating $\left[\mathrm{Co}(\mathrm{CO})_{5}\right]^{+}$at room temperature (r.t.) in ortho-difluorobenzene $(o \mathrm{DFB})^{38}$, its redox potential is too low to oxidize $\mathrm{Fe}(\mathrm{CO})_{5}$. This leads to the formation of the peculiar metal-only Lewis pair $\left[\mathrm{Ag}\left\{\mathrm{Fe}(\mathrm{CO})_{5}\right\}_{2}\right]^{+39,40}$. [NO $]^{+}$ might be a strong enough oxidant (cf.: $E^{\circ}=+1.00 \mathrm{~V}$ vs. $\mathrm{Fc} / \mathrm{Fc}^{+}$in $\left.\mathrm{CH}_{2} \mathrm{Cl}_{2}\right)^{37}$, but it is prone to an inner-sphere electron transfer, which then often leads to a coordination of the resulting NO to the metal center ${ }^{37,41}$. This is also reflected in the reaction of $\left[\mathrm{Co}_{2}(\mathrm{CO})_{8}\right]$ with $[\mathrm{NO}]^{+}$that yielded an inseparable mixture of $\left[\mathrm{Co}(\mathrm{CO})_{5}\right]^{+}$and $\left[\mathrm{Co}(\mathrm{CO})_{2}(\mathrm{NO})_{2}\right]^{+42}$. However, the octahedral configuration of $\mathrm{Cr}(\mathrm{CO})_{6}$ should be kinetically hindered towards substitution due to an energetically disfavored mechanism ${ }^{43}$. This feature enabled using $[\mathrm{NO}]^{+}$as oxidant in combination with the WCAs $\left[\mathrm{Al}\left(\mathrm{OR}^{\mathrm{F}}\right)_{4}\right]^{-}$and $\left[\mathrm{F}-\left\{\mathrm{Al}\left(\mathrm{OR}^{\mathrm{F}}\right)_{3}\right\}_{2}\right]^{-}$. In order to minimize the inevitable $\mathrm{NO} / \mathrm{CO}$-ligand exchange, the 1:1 deelectronation reaction of $\mathrm{Cr}(\mathrm{CO})_{6}$ with $[\mathrm{NO}]^{+}[\mathrm{WCA}]^{-}\left(\mathrm{WCA}:\left[\mathrm{Al}\left(\mathrm{OR}^{\mathrm{F}}\right)_{4}\right]^{-}\right.$or $\left.\left[\mathrm{F}-\left\{\mathrm{Al}\left(\mathrm{OR}^{\mathrm{F}}\right)_{3}\right\}_{2}\right]^{-}\right)$was carried out at low temperatures in $\mathrm{CH}_{2} \mathrm{Cl}_{2}$ $\left(-78^{\circ} \mathrm{C}\right.$ to r.t.). Application of a dynamic vacuum over $1 \mathrm{~h}$ in order to immediately remove the released $\mathrm{NO}$, furnished near quantitative yields of the $17 \mathrm{VE}$ species $\left[\mathrm{Cr}(\mathrm{CO})_{6}\right]^{\bullet+}\left[\mathrm{Al}\left(\mathrm{OR}^{\mathrm{F}}\right)_{4}\right]^{-}$ (1) or $\left[\mathrm{Cr}(\mathrm{CO})_{6}\right]^{\cdot+}\left[\mathrm{F}-\left\{\mathrm{Al}\left(\mathrm{OR}^{\mathrm{F}}\right)_{3}\right\}_{2}\right]^{-}$(2) as off-white to paleyellow solids (Eq. 1). By allowing the reaction to proceed for 7-14 days in a closed vessel at r.t. (Eq. 2), the heteroleptic 18 $\mathrm{VE}$ complexes $\left[\mathrm{Cr}(\mathrm{CO})_{5}(\mathrm{NO})\right]^{+}\left[\mathrm{Al}\left(\mathrm{OR}^{\mathrm{F}}\right)_{4}\right]^{-}(3)$ and $\left[\mathrm{Cr}(\mathrm{CO})_{5}\right.$ $(\mathrm{NO})]^{+}\left[\mathrm{F}-\left\{\mathrm{Al}\left(\mathrm{OR}^{\mathrm{F}}\right)_{3}\right\}_{2}\right]^{-}$(4) were obtained in near quantitative yield as orange solids. Here, the liberated NO displaced one $\mathrm{CO}$ ligand and acts as a $3 \mathrm{e}^{-}$donor (Fig. 1).

The success of the reaction was monitored by gas-phase IR spectroscopy. The loss of either CO or NO was observed in the reactions providing $\mathbf{3}$ and $\mathbf{4}$ or $\mathbf{1}$ and 2, respectively (see S.I. section 8, Supplementary Figures 35 and 36). The purity and phase homogeneity of 1-4 were confirmed by IR and Raman spectroscopy, as well as by phase analysis with powder X-ray diffraction measurements (pXRD, see S.I. section 13, Supplementary Figures 51-58). All complexes are stable at room temperature and can be stored for months under argon atmosphere. In addition, magnetic measurements using the Evans method ${ }^{44}$ in $o \mathrm{DFB} / \mathrm{CH}_{2} \mathrm{Cl}_{2}$ solutions furnished the expected magnetic moments of $2.04 \mu_{\mathrm{B}}$ for $\mathbf{1}$ and $2.06 \mu_{\mathrm{B}}$ for 2 , respectively (see S.I. section 6, Supplementary Table 1, Supplementary Figures 27-32). Hence, apart from being a powerful method for the synthesis of TMCCs, Eq. 2 also opened the door to the family of heteroleptic chromium carbonyl/nitrosyl cations. To put this into perspective, $\left[\mathrm{Cr}(\mathrm{CO})_{5}(\mathrm{NO})\right]^{+}$has only been subject to a few theoretical studies yet ${ }^{45,46}$ and structurally authenticated examples are only known for anionic $\left(\left[\mathrm{Cr}_{2}(\mathrm{CO})_{9}(\mathrm{NO})\right]^{-}, \quad\left[\mathrm{Cr}(\mathrm{CO})_{4}(\mathrm{NO})\right]^{-}\right)^{47-49}$ or neutral $\left(\mathrm{Cr}_{2}(\mathrm{CO})_{8}(\mathrm{NO})_{2}\right)^{47}$ representatives.

Kinetic vs. thermodynamic product. From a series of reactions performed at intermediate temperatures and monitored at

\begin{tabular}{|c|c|c|c|c|c|c|}
\hline$\overline{3 d}$ & {$\left[\mathrm{Mn}(\mathrm{CO})_{6}\right]^{+24}$} & {$\left[\mathrm{Fe}(\mathrm{CO})_{6}\right]^{2+}$} & {$\left[\mathrm{Co}(\mathrm{CO})_{5}\right]^{+}$} & - & $\begin{array}{l}{\left[\mathrm{Cu}(\mathrm{CO})_{n}\right]^{+}} \\
(n=1-4)^{25-27}\end{array}$ & - \\
\hline $4 d$ & {$\left[\mathrm{Tc}(\mathrm{CO})_{6}\right]^{+28}$} & {$\left[\mathrm{Ru}(\mathrm{CO})_{6}\right]^{2+}$} & {$\left[\mathrm{Rh}(\mathrm{CO})_{4}\right]^{+b}$} & $\begin{array}{l}{\left[\mathrm{Pd}(\mathrm{CO})_{4}\right]^{2+b}} \\
{\left[\mathrm{Pd}_{2}(\mu-\mathrm{CO})_{2}\right]^{2+c}}\end{array}$ & $\begin{array}{l}{\left[\mathrm{Ag}(\mathrm{CO})_{n}\right]^{+}} \\
(n=1-2)^{25,27,29}\end{array}$ & - \\
\hline $5 d$ & {$\left[\operatorname{Re}(\mathrm{CO})_{6}\right]^{+}$} & {$\left[\mathrm{Os}(\mathrm{CO})_{6}\right]^{2+}$} & $\begin{array}{l}{\left[\operatorname{lr}(\mathrm{CO})_{4}\right]^{+b}} \\
{\left[\operatorname{lr}(\mathrm{CO})_{6}\right]^{3+}}\end{array}$ & {$\left[\mathrm{Pt}(\mathrm{CO})_{4}\right]^{2+b}$} & {$\left[\mathrm{Au}(\mathrm{CO})_{2}\right]^{+}$} & $\begin{array}{l}{\left[\mathrm{Hg}(\mathrm{CO})_{2}\right]^{2+}} \\
{\left[\mathrm{Hg}_{2}(\mathrm{CO})_{2}\right]^{2+}}\end{array}$ \\
\hline
\end{tabular}


various times, it appeared that the oxidation and formation of 1 and $\mathbf{2}$ is the kinetically preferred reaction pathway, whereas the nitrosyl complexes $\mathbf{3}$ and $\mathbf{4}$ are the thermodynamic final products. Full ab initio calculations at the $\operatorname{CCSD}(\mathrm{T}) / \mathrm{TZ} \rightarrow \mathrm{QZ}$ level (see S.I. section 16, Supplementary Figure 75) support the claim that $\left[\mathrm{Cr}(\mathrm{CO})_{6}\right]^{\cdot+}$ is indeed the kinetic product in $\mathrm{CH}_{2} \mathrm{Cl}_{2}$ as solvent $\left(\Delta_{\mathrm{r}} H_{\text {gas }}^{\circ} / \Delta_{\mathrm{r}} G_{\text {solv }}^{\circ}=-83 /-30 \mathrm{~kJ} \mathrm{~mol}^{-1}\right.$ for $\left[\mathrm{Cr}(\mathrm{CO})_{6}\right]^{\bullet+}$ (Eq. 1) vs. $-232 /-173 \mathrm{~kJ} \mathrm{~mol}^{-1}$ for $\left[\mathrm{Cr}(\mathrm{CO})_{5} \mathrm{NO}\right]^{+}$, Eq. 2). The high reactivity of $[\mathrm{NO}]^{+}$and rather poor solubility of $\mathbf{1}$ and 2 in $\mathrm{CH}_{2} \mathrm{Cl}_{2}$ seem to be crucial for the success of the reaction (Eq. 1), since it leads to a quick formation of the relatively stable

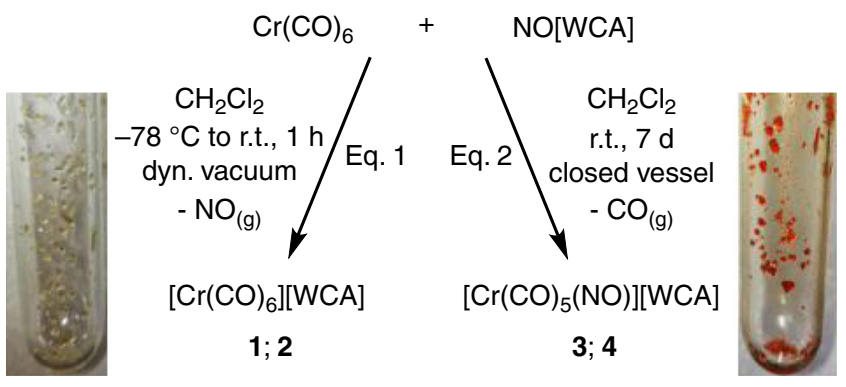

Fig. 1 Reaction scheme yielding complexes 1 and $\mathbf{2}$ (Eq. 1) as well as $\mathbf{3}$ and $\mathbf{4}$ (Eq. 2). The pictures show the crystalline complexes $\mathbf{1}$ (pale yellow) and $\mathbf{3}$ (orange)
$\left[\mathrm{Cr}(\mathrm{CO})_{6}\right]^{\bullet+}$ intermediate that shortly after precipitates at low temperatures. By contrast, carrying out the reaction in oDFB, where all the products are well dissolved, apparently led to a less reactive $[\mathrm{NO}]^{+}$and therefore only the isolation of $\left[\mathrm{Cr}(\mathrm{CO})_{5}(\mathrm{NO})\right]^{+}$. We note that the reaction of the obviously formed charge-transfer $\pi$-complex $\left[\mathrm{NO}^{+}{ }_{-} o \mathrm{DFB}\right]$ with $\mathrm{Cr}(\mathrm{CO})_{6}$ must be faster than the formation of a Wheland-intermediate and nitrosation of the solvent. However, once pure 3 and 4 were prepared, their crystals dissolve unchanged in $o$ DFB.

Vibrational spectroscopy. The solid state ATR IR spectra (Fig. 2 and Table 2; ATR $=$ attenuated total reflection) of $\mathbf{1}$ and $\mathbf{2}$ show a single broadened CO band at $2094 \mathrm{~cm}^{-1}$ (small ${ }^{13} \mathrm{CO}$ shoulder at about $2070 \mathrm{~cm}^{-1}$ ), which verifies the assumptions made of a possible $\left[\mathrm{Cr}(\mathrm{CO})_{6}\right]^{\bullet+}$ in a previous matrix study ${ }^{50}$. The respective Raman spectra show a sharp band at about $2174 \mathrm{~cm}^{-1}$ for the all-symmetric stretch vibration, as well as a broad band centered around $2127 \mathrm{~cm}^{-1}$. The position and shape of these bands are in agreement with the Raman spectrum of the isoelectronic but neutral $D_{3 \mathrm{~d}}$-symmetric $\mathrm{V}(\mathrm{CO})_{6}$ (cf. Table 2 and Supplementary Figure 34$)^{51}$.

A Jahn-Teller-induced fluxionality at room temperature leads to the broad band at about $2127 \mathrm{~cm}^{-1}$ not affecting the all-symmetric stretching mode. This fluxionality freezes out in the vanadium case only at temperatures below $16 \mathrm{~K}$. At higher temperatures, a very low-lying transition state probably allows for equilibration-even

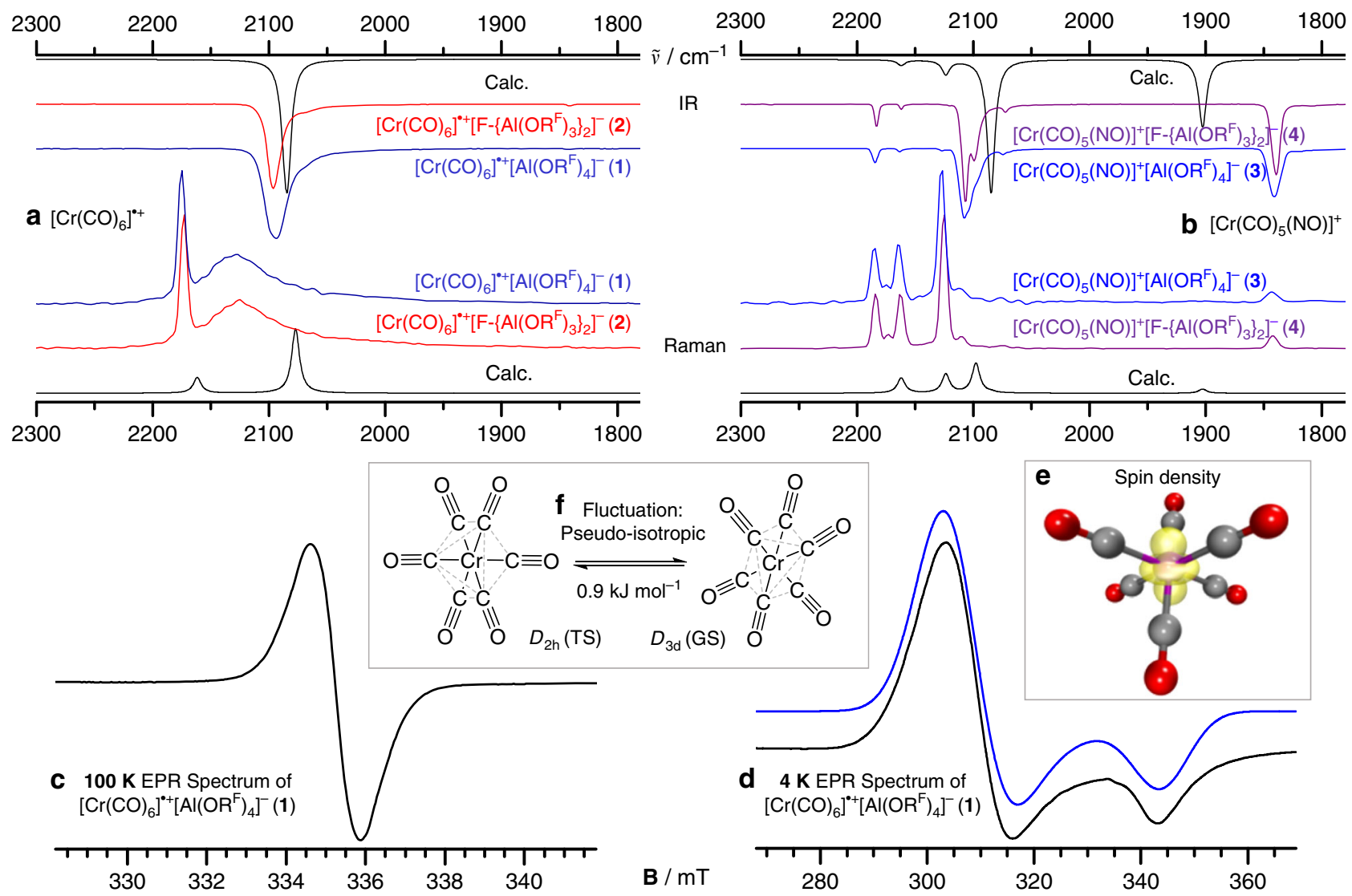

Fig. 2 Block figure showing essential IR, Raman, and EPR spectra of complexes 1-4. a, b Stacked IR and Raman spectra of compounds 1 (dark blue), 2 (red), $\mathbf{3}$ (blue), 4 (purple), and the respective simulated calculated spectra (black, BP86-D3BJ/def2-TZVPP) of the cations in the CO/NO stretching range between 1800 and $2300 \mathrm{~cm}^{-1}$; For the full spectra, including an assignment of all bands see Supplementary Figures 42-49 and Supplementary Tables 2, 3 . c EPR spectrum of $\mathbf{1}$ at X-Band $(9.4002 \mathrm{GHz})$ in a frozen solution of a 1:1 (v:v) mixture of oDFB and toluene at $100 \mathrm{~K}$. $\mathbf{d}$ Experimental (black) and simulated (blue) EPR spectrum of $\mathbf{1}$ at X-Band $(9.37821 \mathrm{GHz})$ in a frozen solution of oDFB at $4 \mathrm{~K}$ in agreement with the $D_{3 \mathrm{~d}}$ ground state. e Calculated spin density of $D_{3 d}-\left[\mathrm{Cr}(\mathrm{CO})_{6}\right]^{0^{+}}$at the SA-CASSCF/cc-pVTZ level of theory. Isovalue at 0.02 a.u. $\mathbf{f}$ Equilibration path that transforms the two equivalent $D_{3 d}$ ground states (GS) at $100 \mathrm{~K}$ over a low-lying $D_{2 \mathrm{~h}}$ transition state (TS), yielding a coalescent signal in the $100 \mathrm{~K}$ EPR spectrum 
Table 2 Experimental (exp.) and calculated (calcd.) vibrational spectra of $\left[\mathrm{Cr}(\mathrm{CO})_{6}\right]^{\bullet+},\left[\mathrm{Cr}(\mathrm{CO})_{5}(\mathrm{NO})\right]^{+}$, and the isoelectronic vanadium analogs $\mathbf{s}^{\mathrm{a}}$

\begin{tabular}{|c|c|c|c|c|c|c|c|c|}
\hline \multicolumn{3}{|l|}{ IR Spectra } & \multicolumn{4}{|c|}{ Raman spectra } & \multirow{2}{*}{$\frac{\mathbf{I R}^{\mathbf{b}}}{\text { Exp. } \mathrm{V}(\mathrm{CO})_{6} 51}$} & \multirow[t]{2}{*}{ Ramanc $^{c}$} \\
\hline Calcd. (I)d & 1 & 2 & 1 & 2 & Calcd. $(I)^{d}$ & $D_{3 d}$ & & \\
\hline $2157(0)$ & \multirow{4}{*}{$2094(s)$} & \multirow{4}{*}{2096 (s) } & \multirow[t]{3}{*}{$2175(s)$} & \multirow[t]{3}{*}{$2173(s)$} & 2157 (208) & $A_{1 \mathrm{~g}}$ & & \multirow[t]{4}{*}{$2102(12.5)$} \\
\hline $2084(816)$ & & & & & $2084(0)$ & $A_{2 \mathrm{u}}$ & \multirow{3}{*}{$\begin{array}{l}1991(54) \\
1985(100)\end{array}$} & \\
\hline 2081 (999) & & & & & $2081(0)$ & $E_{\mathrm{u}}$ & & \\
\hline $2074(0)$ & & & 2128 (br, vs) & 2126 (br, vs) & 2074 (413) & $E_{g}$ & & \\
\hline Calcd. $(I)^{d}$ & 3 & 4 & 3 & 4 & Calcd. $(I)^{d}$ & $C_{4 v}$ & \multicolumn{2}{|l|}{ Exp. $\mathrm{V}(\mathrm{CO})_{5}(\mathrm{NO})^{52}$} \\
\hline $2161(91)$ & 2184 (vw) & 2183 (vw) & $\begin{array}{l}2185(\mathrm{~m}) \\
{[2175(\mathrm{vw})]^{\mathrm{e}}}\end{array}$ & $\begin{array}{l}2184(\mathrm{~m}) \\
{[2173(\mathrm{vw})]^{\mathrm{e}}}\end{array}$ & 2161 (177) & $A_{1}$ & $2100(w)$ & \multirow[t]{7}{*}{ Not available } \\
\hline $2123(91)$ & 2164 (vvw) & 2162 (vvw) & $2164(\mathrm{~m})$ & $2163(\mathrm{~m})$ & 2123 (217) & $A_{1}$ & $2050(w)$ & \\
\hline $2097(0)$ & 2127 (vvw) & & 2127 (vvs) & 2125 (vvs) & 2097 (340) & $B_{2}$ & & \\
\hline \multirow[t]{3}{*}{2085 (1055) } & $2108(\mathrm{~ms})$ & 2107 (vs) & $2112(\mathrm{vw})$ & $2110(\mathrm{vvw})$ & $2085(5)$ & $E$ & \multirow[t]{3}{*}{1990 (s) } & \\
\hline & & $2099(m)^{f}$ & & & & & & \\
\hline & 2074 (vvw)g & $2072(v v w) g$ & $2076(v v w) g$ & $2074($ vvw)g & & ${ }^{13} \mathrm{COg}$ & & \\
\hline 1899 (1052) & $1841(\mathrm{mw})$ & 1839 (ms) & 1843 (vvw) & $1842(\mathrm{vvw})$ & 1899 (39) & $A_{1} \mathrm{NO}$ & $1695(\mathrm{~m})$ & \\
\hline \multicolumn{9}{|c|}{ 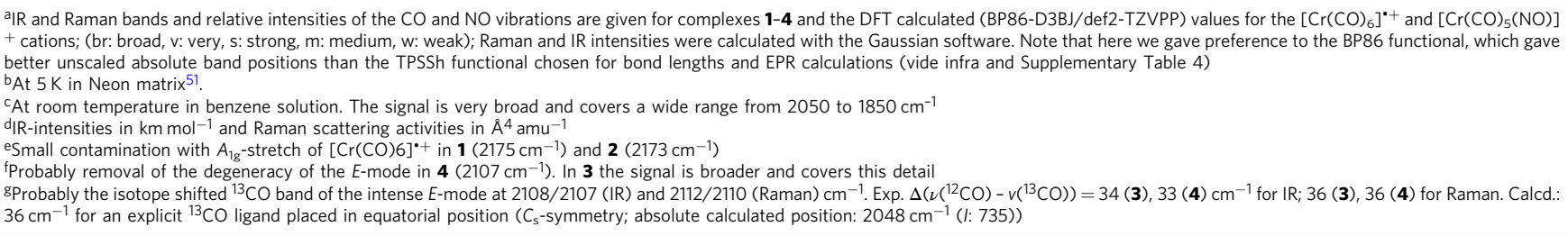 } \\
\hline
\end{tabular}

Table 3 Comparison of experimental (exp.) and theoretical (calcd.) bond lengths of 1-4 and selected literature complexes

\begin{tabular}{|c|c|c|c|c|c|c|c|c|c|}
\hline & Exp. bond & Lengths (pm) ${ }^{a}$ & & & \multirow{2}{*}{ Exp. bond } & \multirow[t]{2}{*}{ Lengths $(\mathrm{pm})^{\mathbf{b}}$} & \multirow{2}{*}{$\frac{\text { Calcd. bond }}{\left[\mathrm{Cr}(\mathrm{CO})_{6}\right]^{+}}$} & \multicolumn{2}{|l|}{ Lengths (pm)c } \\
\hline & {$\left[\mathrm{Al}\left(\mathrm{OR}^{\mathrm{F}}\right)_{4}\right]^{-}$} & & \multicolumn{2}{|l|}{$\left[\mathrm{F}-\left\{\mathrm{Al}\left(\mathrm{OR}^{\mathrm{F}}\right)_{3}\right\}_{2}\right]^{-}$} & & & & {$\left[\mathrm{Cr}(\mathrm{CO})_{5}(\mathrm{NO})\right]^{+}$} & $\mathrm{Cr}(\mathrm{CO})_{6}$ \\
\hline $\begin{array}{l}\mathrm{Cr}-\mathrm{C} 1 \\
\mathrm{Cr}-\mathrm{C} 2^{\mathrm{d}} \\
\mathrm{Cr}-\mathrm{C} 3\end{array}$ & $\begin{array}{l}{\left[\mathrm{Cr}(\mathrm{CO})_{6}\right]^{+}} \\
196.2(3) \\
199.1(1) \\
196.9(3)\end{array}$ & $\begin{array}{l}{\left[\mathrm{Cr}(\mathrm{CO})_{5}(\mathrm{NO})\right]^{+}} \\
195.8(3) \\
196.2(1) \\
192.4(3)\end{array}$ & $\begin{array}{l}{\left[\mathrm{Cr}(\mathrm{CO})_{6}\right]^{+}} \\
198.2(2)\end{array}$ & $\begin{array}{l}{\left[\mathrm{Cr}(\mathrm{CO})_{5}(\mathrm{NO})\right]^{+}} \\
194.9(4)\end{array}$ & $\begin{array}{l}\mathrm{Cr}(\mathrm{CO})_{6} 53 \\
191.4(1)^{5} \\
191.1(1)^{\mathrm{e}} \\
190.9(1) \\
191.7(1)^{\mathrm{e}}\end{array}$ & $\begin{array}{l}\mathrm{V}(\mathrm{CO})_{6} 54 \\
199.3(5) \\
199.4(5)^{\mathrm{e}} \\
200.3(4) \\
200.6(4)^{\mathrm{e}}\end{array}$ & $\begin{array}{l}D_{3 d} \\
197.5\end{array}$ & $\begin{array}{l}C_{4 v} \\
202.0 \\
195.8 \\
172.9(\mathrm{Cr}-\mathrm{N})\end{array}$ & $\begin{array}{l}O_{h} \\
190.9\end{array}$ \\
\hline $\mathrm{C} 1-\mathrm{O} 1$ & $112.4(3)$ & $112.4(3)$ & $112.2(2)$ & $112.5(5)$ & $114.2(1)$ & $113.3(4)$ & 113.0 & 112.6 & 114.4 \\
\hline $\mathrm{C} 2-\mathrm{O} 2^{\mathrm{d}}$ & $112.0(1)$ & $112.5(2)$ & & & $114.2(1)^{\mathrm{e}}$ & $113.9(4)^{\mathrm{e}}$ & & 113.1 & \\
\hline $\mathrm{C} 3-\mathrm{O} 3$ & $112.4(3)$ & $113.0(3)$ & & & $\begin{array}{l}114.4(1) \\
113.9(1)^{\mathrm{e}}\end{array}$ & $\begin{array}{l}113.3(3) \\
112.4(3)^{\mathrm{e}}\end{array}$ & & $113.6(\mathrm{~N}-\mathrm{O})$ & \\
\hline Avg. ${ }^{f} \mathrm{Cr}-\mathrm{C}$ & $198.6(4)$ & $195.6(4)$ & $198.2(2)$ & $194.9(4)$ & $191.3(2)$ & $199.9(9)$ & 197.5 & 193.0 & 190.9 \\
\hline Avg. ${ }^{f} \mathrm{C}-\mathrm{O}$ & $112.1(4)$ & $112.6(5)$ & $112.2(2)$ & $112.5(5)$ & $114.1(2)$ & $113.2(7)$ & 113.0 & 113.1 & 114.4 \\
\hline $\begin{array}{l}{ }^{a} \text { This work } \\
\text { bFrom literat } \\
\text { CTPSSh-D3BJ } \\
{ }^{\text {d }} \text { Ligand on th } \\
\text { e }{ }^{2} C_{2} \text {-symmetr } \\
{ }^{\circ} \text { Mean error }\end{array}$ & $\begin{array}{l}\text { f2-TZVPP } \\
4 \text {-symmetry ax } \\
\text { kis } \\
\text { ond lengths we }\end{array}$ & ulated accordir & ussian error prop & & & & & & \\
\hline
\end{tabular}

on the fast time scale of vibrational spectroscopy, leading to the discrepancy between experimental and the $D_{3 \mathrm{~d}^{-}}$simulated spectrum. This assignment is in agreement with the EPR spectra as well as DFT and ab initio calculations for the cation (vide infra, Table 3). The presence of a band of very low intensity at about $1840 \mathrm{~cm}^{-1}$ is indicative for the formation of very small amounts of the (by-) products $\left[\mathrm{Cr}(\mathrm{CO})_{5}(\mathrm{NO})\right]^{+} \mathbf{3}$ and 4 . Furthermore, as opposed to $\mathbf{1}$ and 2, some $\mathrm{Cr}-\mathrm{N}$ and $\mathrm{Cr}-\mathrm{C}$ vibrations at $658 / 640 \mathrm{~cm}^{-1}$ (IR) and $640 / 487 \mathrm{~cm}^{-1}$ (Raman) are not obscured by anion bands and can be assigned unambiguously (cf. Supplementary Figure 33). Their entire vibrational spectra are in good agreement with the simulation (Fig. 2), as well as the known bands of the isoelectronic neutral $\mathrm{V}$ $(\mathrm{CO})_{5}(\mathrm{NO})^{52}$ (Table 2).

Molecular structures. Quite unsurprisingly and due to their very similar molecular structure, the pale yellow complexes 1, 2 and the orange colored complexes $\mathbf{3}, \mathbf{4}$ are isostructural. The high symmetry of the crystal structures of $\mathbf{1}$ and $\mathbf{3}$ (tetragonal, $P 4 / n$ ) leads to only three symmetry-independent ligands, rendering a differentiation between the $\mathrm{NO}$ or $\mathrm{CO}$ positions impossible. Even more so for $\mathbf{2}$ and $\mathbf{4}$, where the cubic structures $(P a \overline{3})$ include only one symmetry-independent ligand (Supplementary Figure 68 and Supplementary Figure 71). Yet, spectroscopically clean pale yellow colored (orange colored) crystals suitable for single crystal XRD (scXRD), in agreement with an assignment as $\mathbf{1}$ and 2 (3 and 4), were isolated from batches of reactions according to Eq. 1 (Eq. 2) (Fig. 3).

The observed average $\mathrm{Cr}$-ligand bond lengths are about $3 \mathrm{pm}$ shorter for 3 and 4 . This is consistent with the shorter (calculated) $\mathrm{Cr}-\mathrm{N}$ bond length (Table 3 ) and is in addition reflected in smaller unit cell volumes of $\mathbf{3}$ and $\mathbf{4}$, if compared to $\mathbf{1}$ and 2 . In addition, this also holds for the bulk microcrystalline powders of all compounds 1-4, as shown by full Rietveld-refinement of powder XRD data collected at $100 \mathrm{~K}$ (see S.I. section 13, Supplementary Table 7). Overall, the determined experimental parameters and the 

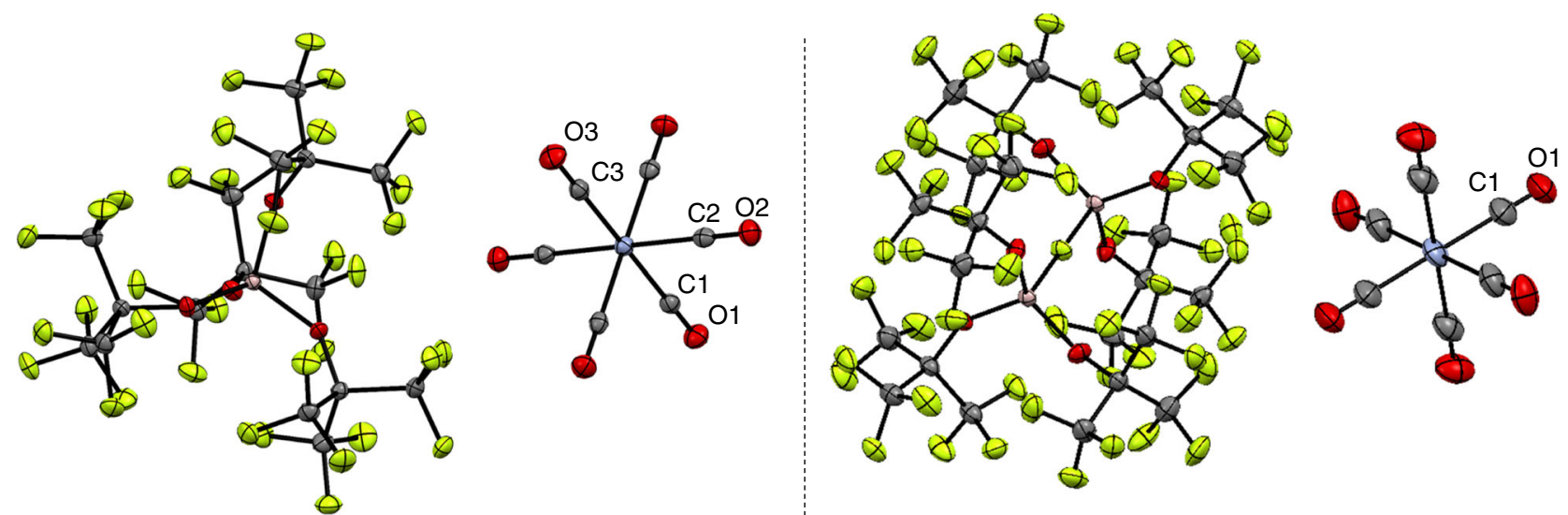

Fig. 3 Molecular structures of complexes 1-4. Pale yellow colored (orange colored) crystals suitable for scXRD and with spectroscopic data in agreement with an assignment as $\mathbf{1}$ and $\mathbf{2}$ ( $\mathbf{3}$ and $\mathbf{4}$ ) were isolated from batches of reactions according to Eq. 1 (Eq. 2). However, the respective nitrogen position was never crystallographically distinguishable from the carbon positions. Therefore, only one set of molecular structures is shown: $\mathbf{1}$ and $\mathbf{3}$ (left) and $\mathbf{2}$ and $\mathbf{4}$ (right). Inclusion of a disordered nitrogen atom into the refinement did only slightly change the agreement factors (Supplementary Figures 70 and 72 ). Nevertheless, the average bond lengths are about 3 pm shorter for $\mathbf{3}$ and $\mathbf{4}$, which agrees with the (calculated) shorter $\mathrm{Cr}-\mathrm{N}$ bond length and the observed smaller unit cell volumes. Only crystallographically independent atoms were labeled; ellipsoids are shown at 50\% probability level. See Table 3 for information on metric data

results of DFT calculations collected in Table 3 are in good agreement and in accordance with the reported bond lengths for $\mathrm{Cr}$ $(\mathrm{CO})_{6}^{53}$ and $\mathrm{V}(\mathrm{CO})_{6}^{54}$.

EPR spectroscopy. To verify the identity of the $\left[\mathrm{Cr}(\mathrm{CO})_{6}\right]^{\bullet+}$ radical cation, a diluted frozen solution of 1 in a $1: 1$ (v:v) mixture of $o$ DFB and toluene (pure oDFB solutions led to very noisy spectra) was investigated by means of X-band EPR spectroscopy at $100 \mathrm{~K}$ (Fig. 2c). The paramagnetic $17 \mathrm{VE} d^{5}$ species gives rise to one single EPR-line corresponding to an isotropic $g$-value of $g=2.003$ being close to the $g$-factor of the free electron $\left(g_{\mathrm{el}}=\right.$ $2.0023)^{55}$. Similar $g$-values were reported for tetra-, tri-, and dicarbonyl chromium(I) phosphine and phosphite complexes ${ }^{56}$. In contrast to prior EPR investigations from electrochemical oxidations $^{33}$, we did not observe any signal splitting due to hyperfine coupling to the ${ }^{53} \mathrm{Cr}$ nucleus $(I=3 / 2$, natural abundance: $9.55 \%$ ). Probably any coupling pattern is hidden by the line broadening in the EPR spectra, since our calculations of hyperfine couplings (HFCs) reveal isotropic coupling constants always lower than $30 \mathrm{MHz}$ (Supplementary Table 5). Note, however, that a larger hyperfine coupling of $61 \mathrm{MHz}$ was reported for a species assigned as $\left[\mathrm{Cr}(\mathrm{CO})_{6}\right]^{\bullet+}$ and generated by in situ electrolysis of $\mathrm{Cr}(\mathrm{CO})_{6}$ in saturated solutions of $\left[\mathrm{NBu}_{4}\right]^{+}\left[\mathrm{ClO}_{4}\right]^{-}$ in $\mathrm{CH}_{2} \mathrm{Cl}_{2}$ at $-80^{\circ} \mathrm{C}^{33}$. This ${ }^{53} \mathrm{Cr}$ hyperfine coupling is about three times larger than the coupling constants of chromium(I) carbonyl phosphine and phosphite complexes ${ }^{56}$. Furthermore, the $g$-value of $g=2.003$ we identified for $\mathbf{1}$ is larger than the one previously reported $(g=1.982)^{33}$. We note, however, that the presence of the-compared to our WCAs-much stronger coordinating perchlorate anion in the experimental setup may have led to ion-pair formation, thus shifting the $g$-value with respect to the naked $\left[\mathrm{Cr}(\mathrm{CO})_{6}\right]^{\bullet+}$ cation. Our isotropic $g$-value obtained at $100 \mathrm{~K}$ would be consistent with an octahedral symmetry $\mathrm{O}_{\mathrm{h}}$ of the $\left[\mathrm{Cr}(\mathrm{CO})_{6}\right]^{\bullet+}$ cation. However, the $d^{5}$ complex should be subject to a dynamical Jahn-Teller effect, lowering its symmetry as it was found in the crystal structure of $\mathbf{1}$ and $\mathbf{2}$ and that of the isoelectronic $\mathrm{V}(\mathrm{CO})_{6}$, which has $D_{3 \mathrm{~d}}$ symmetry in its electronic ground state ${ }^{51}$ (see S.I. section 9 for an in-depth discussion). Consequently, the pseudo-isotropic signal at $100 \mathrm{~K}$ may result from a thermal fluctuation of different Jahn-Teller distorted $\left[\mathrm{Cr}(\mathrm{CO})_{6}\right]^{\bullet+}$ structures (e.g., the $D_{3 \mathrm{~d}}-D_{2 \mathrm{~h}}-D_{3 \mathrm{~d}}$ sequence shown in Fig. $2 \mathrm{f}$ and also suggested for $\left.\mathrm{V}(\mathrm{CO})_{6}{ }^{51}\right)$. To verify this

\begin{tabular}{|c|c|c|c|c|c|c|}
\hline & Exp. & $D_{3 d}$ & $C_{2 h}$ & $D_{4 h}$ & $D_{2 h}^{b}$ & $O_{h}{ }^{c}$ \\
\hline$\Delta E$ & & $0(0.00)$ & $26(0.31)$ & $136(1.63)$ & $71(0.85)$ & $410(4.92)$ \\
\hline$g_{\perp}$ & 2.185 & 2.173 & 2.177 & 2.434 & & \\
\hline$g_{\|}$ & 1.947 & 1.971 & 1.969 & 1.761 & & \\
\hline$g_{\text {iso }} d$ & 2.106 & 2.106 & 2.108 & 2.210 & & \\
\hline \multicolumn{7}{|c|}{$\begin{array}{l}\text { aElectronic energies were calculated with DLPNO-CCSD }(T) / \text { def2-TZVPP }\left(E \text { in } \mathrm{cm}^{-1} ; \mathrm{kJ} \mathrm{mol}^{-1}\right. \\
\text { in parentheses), structures were optimized with TPSSh-D BBJ/def2-TZVPP; the calculated } \\
\text { (NEVPT2-SA-CAS-SCF/CC-pVTZ) anisotropic } g \text {-tensor components perpendicular }\left(g_{\perp}\right) \text { and } \\
\text { parallel }\left(g_{\|}\right) \text {to the principal molecular axis as well as isotropic } g \text {-values for the minimum } \\
\text { structures } D_{3 d}, C_{2 h} \text { and } D_{4 h} \text { are compared to the experimental values (exp.) } \\
\text { bTransition state structure connecting two equivalent } D_{3 d} \text { symmetric structures } \\
{ }_{\text {CNot a stationary point }} \\
{ }^{\mathrm{d}} g_{\text {iso }}=\left(2^{\star} g_{\perp}+g_{\|\|}\right) / 3\end{array}$} \\
\hline
\end{tabular}

assumption, we conducted EPR measurements of $\mathbf{1}$ at $4 \mathrm{~K}$. At this temperature, the spectrum indicates axial anisotropy with two principle $g$-values of $g_{\|}=1.953$ and $g_{\perp}=2.156$, being consistent with an axial $D_{3 \mathrm{~d}^{-}}$-symmetry of the $\left[\mathrm{Cr}(\mathrm{CO})_{6}\right]^{\bullet+}$ cation (Fig. $2 \mathrm{~d}$ ).

Ab initio and DFT investigations. To complete the answer to the question of the correct point group of the $\left[\mathrm{Cr}(\mathrm{CO})_{6}\right]^{\bullet+}$ cation, we performed symmetry restricted structure optimizations at the TPSSh/def2-TZVPP level of theory. In a comparative study, we found the TPSSh functional to yield reasonable structural parameters (Supplementary Table 4). The so-obtained structures were used for DLPNO-CCSD(T) single-point electronic energy calculations. In addition, we calculated $g$-tensors for minimum structures by means of the NEVPT2-SA-CAS-SCF method. The results are summarized in Table 4.

In accordance with an extensive study ${ }^{51}$ of the isoelectronic $\mathrm{V}(\mathrm{CO})_{6}$ complex, we found the $D_{3 \mathrm{~d}}$ structure to be the lowest in energy. The $D_{2 \mathrm{~h}}$ structure is a transition state connecting two equivalent $D_{3 \mathrm{~d}}$ minima. Alike, the $O_{\mathrm{h}}$ symmetric structure is not a stationary point and convergence in the SCF procedure can only be achieved by allowing (unphysical) broken occupation numbers in the unrestricted treatment. Similar to $\mathrm{V}(\mathrm{CO})_{6} 57$, we identified a $C_{2 \mathrm{~h}}$ symmetric structure, which shows only a very small structural and energetic deviation from the $D_{3 \mathrm{~d}}$ one. We note that the 
calculated minimal relative energy of the $D_{2 \mathrm{~h}}$ transition state $\left(+0.85 \mathrm{~kJ} \mathrm{~mol}^{-1}\right)$ is in perfect agreement with the EPR observation of a fluxional structure at $100 \mathrm{~K}$. Thermal energy corresponds to $0.83 \mathrm{~kJ} \mathrm{~mol}^{-1}$ at $100 \mathrm{~K}$. Only at considerably lower temperature $(4 \mathrm{~K})$ the structure is static. The $D_{4 \mathrm{~h}}$ symmetric structure is a local minimum notably higher in energy and seems only to be accessible on the potential energy surface by passing the $D_{2 \mathrm{~h}}$ transition state to higher energies. Furthermore, the CASSCF calculations yield a much more anisotropic $g$-tensor for the $D_{4 \mathrm{~h}}$ structure than for the $D_{3 \mathrm{~d}}$ one. Hence, even though there is some deviation, the comparison of calculated and experimental $g$ values clearly confirms the $\left[\mathrm{Cr}(\mathrm{CO})_{6}\right]^{{ }^{+}+}$cation to have a $D_{3 \mathrm{~d}}$ symmetric ground state structure. Thus, the symmetry taken by the $\left[\mathrm{Cr}(\mathrm{CO})_{6}\right]^{\bullet+}$ cation in the crystal structure-best realized in the cubic structure $\mathbf{2}$ with an isolated $\mathrm{Cr}-\mathrm{CO}$ moiety residing on a $\overline{3}$-position of local $D_{3 \mathrm{~d}}$ site symmetry-is really rooted in its electronic structure and not caused by interactions with the anion or crystal packing effects. This is in agreement with our claim that the WCA $\left[\mathrm{F}-\left\{\mathrm{Al}\left(\mathrm{OR}^{\mathrm{F}}\right)_{3}\right\}_{2}\right]^{-}$is one of the least coordinating anions known ${ }^{58}$ and as such truly introduces pseudo-gas phase conditions in the solid state ${ }^{59}$.

\section{Discussion}

The right combination of $[\mathrm{NO}]^{+}$as oxidant with the WCAs $\left[\mathrm{Al}\left(\mathrm{OR}^{\mathrm{F}}\right)_{4}\right]^{-}$and $\left[\mathrm{F}-\left\{\mathrm{Al}\left(\mathrm{OR}^{\mathrm{F}}\right)_{3}\right\}_{2}\right]^{-}$and the unique reactivity of $\mathrm{Cr}(\mathrm{CO})_{6}$ gives facile access to the unexplored field of homoleptic $17 \mathrm{VE}$ radical carbonyl cations, as well as heteroleptic $18 \mathrm{VE}$ chromium carbonyl/nitrosyl cations. $\left[\mathrm{Cr}(\mathrm{CO})_{6}\right]^{\cdot+}[\mathrm{WCA}]^{-}$shows surprising stability and is closely related to the isoelectronic and isostructural $\mathrm{V}(\mathrm{CO})_{6}$ with the same $D_{3 \mathrm{~d}}$ symmetric ground state, which is supported by experimental IR, Raman, and EPR spectroscopic investigations, as well as magnetic measurements and calculated DFT/full ab initio data. Apart from its textbook importance, $\left[\mathrm{Cr}(\mathrm{CO})_{6}\right]^{\bullet+}$ might be a valuable $17 \mathrm{VE}$ metalloradical precursor for substitution chemistry, which is not part of this report. Especially, follow-up chemistry and take up by others is facilitated by the access to $\mathbf{1}$ and $\mathbf{2}$ using standard glassware, organic solvents, and commercially available starting materials. We expect transfer of this methodology to other transition metal carbonyls. Of those, the group 6 metal carbonyls molybdenum and tungsten are currently in our focus.

\footnotetext{
Methods

General. Full details of the employed methods and additional information are given in Supplementary Information: pictures of the glassware used and the compounds themselves (Supplementary Figures 1-4); synthesis and spectra of

$\mathrm{NO}\left[{ }^{\mathrm{F}}-\left\{\mathrm{Al}\left(\mathrm{OR}^{\mathrm{F}}\right)_{3}\right\}_{2}\right]$ (Supplementary Figures 5-8); EPR spectroscopy (Supplementary Figure 37, Supplementary Tables 4 and 5, Supplementary Data 1); calculated geometries (Supplementary Figures 76 and 77, Supplementary Data 8-11), simulated spectra (Supplementary Figures 38-41) and calculated energies (Supplementary Figure 75, Supplementary Tables 10 and 11); UV/Vis spectra (Supplementary Figure 50); crystal structures (Supplementary Figures 67-72, Supplementary Data 2-7, Supplementary Tables 8 and 9) and Hirshfeld plots (Supplementary Figures 73 and 74). For space restrictions, here we only report the data of the $\left[\mathrm{Al}\left(\mathrm{OR}^{\mathrm{F}}\right)_{4}\right]^{-}$salts. However, all experimental details for the $\left[\mathrm{F}-\left\{\mathrm{Al}\left(\mathrm{OR}^{\mathrm{F}}\right)_{3}\right\}_{2}\right]$ salts and their spectra are given as well (Supplementary Figures 13-16, 22-26 (NMR), Supplementary Figures 44, 45, 48, 49 (IR/Raman)). For all compounds, pXRD measurements including Rietveld refinements strongly support their phase pure nature (Supplementary Figures 51-66). Elemental analyses proved to be unreliable for salts with these kinds of anions; a more thorough discussion is given in the Supplementary Information (S.I. section 12 and Supplementary Table 6).
}

Synthesis of $\left[\mathbf{C r}(\mathbf{C O})_{6}\right]\left[A I\left(\mathbf{O R}^{\mathbf{F}}\right)_{4}\right]$ (1). A double-Schlenk flask was equipped inside the glove box with $\mathrm{Cr}(\mathrm{CO})_{6}\left(51 \mathrm{mg}, 0.232 \mathrm{mmol}, 1\right.$ eq.) and $\mathrm{NO}\left[\mathrm{Al}\left(\mathrm{OR}^{\mathrm{F}}\right)_{4}\right]$ (230 mg, $0.231 \mathrm{mmol}, 1$ eq.). Then, $\mathrm{CH}_{2} \mathrm{Cl}_{2}(\sim 4 \mathrm{~mL})$ was condensed at $-196{ }^{\circ} \mathrm{C}$ onto the reaction mixture and it was allowed to thaw to $-78^{\circ} \mathrm{C}$ under dynamic vacuum. Upon dissolution, the color turned initially blue and a gas evolution was visible. The mixture was stirred under dynamic vacuum (so that the solvent was very mildly boiling) until it reached r.t. over the period of an hour. The $\mathrm{CH}_{2} \mathrm{Cl}_{2}$ $(\sim 2 \mathrm{~mL})$ was then filtered off and the remaining solid was dried in vacuo in order to yield 1 as an off-white to beige solid $(260 \mathrm{mg}, 0.219 \mathrm{mmol}, 94 \%)$. Single crystals were obtained by slow vapor diffusion of $n$-pentane in a solution of $\mathbf{1}$ in 1,2 $\mathrm{F}_{2} \mathrm{C}_{6} \mathrm{H}_{4}(o \mathrm{DFB})$ at r.t. FTIR (ZnSe, ATR): $\tilde{v} / \mathrm{cm}^{-1}$ (intensity) $=2094(\mathrm{~s}), 1843$ $\left(\mathrm{vvw}\right.$, trace of $\left.\left[\mathrm{Cr}(\mathrm{CO})_{5}(\mathrm{NO})\right]^{+}\right), 1508(\mathrm{vvw}$, trace of residual oDFB), $1352(\mathrm{vw})$, $1298(\mathrm{mw}), 1272(\mathrm{~ms}), 1239$ (s), 1208 (vvs), 1161 (ms), 969 (vvs), 831 (vw), 756 (vvw), 726 (vvs), 571 (vvw), 560 (vw) (Supplementary Figure 42). FT Raman (1000 scans, $\left.100 \mathrm{~mW}, 4 \mathrm{~cm}^{-1}\right): \tilde{v} / \mathrm{cm}^{-1}$ (intensity) $=2175$ (vvs), $2128(\mathrm{mw}), 2062$ (vw), 1304 (vvw), 1272 (vvw), 1235 (vvw), 1163 (vvw), 977 (vvw), 798 (w), 747 (w), $572(\mathrm{vvw}), 563$ (vvw), $538(\mathrm{vw}), 368(\mathrm{vvw}), 332(\mathrm{~m}), 288(\mathrm{w}), 234(\mathrm{vvw}), 173(\mathrm{vvw})$ (Supplementary Figure 43). ${ }^{1} \mathrm{H}$ NMR $(400.17 \mathrm{MHz}, o \mathrm{DFB}, 298 \mathrm{~K})$ : only solvent signals; ${ }^{13} \mathrm{C}\left\{{ }^{1} \mathrm{H}\right\}$ NMR $(100.62 \mathrm{MHz}, o \mathrm{DFB}, 298 \mathrm{~K}): \delta / \mathrm{ppm}=121.7\left(\mathrm{q},{ }^{1} \mathrm{~J}(\mathrm{C}, \mathrm{F})=\right.$ $293 \mathrm{~Hz}, 12 \mathrm{C}, \mathrm{CF}_{3}$, in part overlapped by solvent signals); ${ }^{19} \mathrm{~F}$ NMR $(376.54 \mathrm{MHz}$ $o \mathrm{DFB}, 298 \mathrm{~K}): \delta / \mathrm{ppm}=-75.3\left(\mathrm{~s}, 36 \mathrm{~F}, 4 \times \mathrm{C}\left(\mathrm{CF}_{3}\right)_{3}\right) ;{ }^{27} \mathrm{Al} \mathrm{NMR}(104.27 \mathrm{MHz}$, $o \mathrm{DFB}, 298 \mathrm{~K}): \delta / \mathrm{ppm}=35.0\left(\mathrm{~s}, 1 \mathrm{Al}, \mathrm{Al}\left(\mathrm{OR}^{\mathrm{F}}\right)_{4}\right)$ (Supplementary Figures 9-12).

Synthesis of $\left[\mathrm{Cr}(\mathrm{CO})_{5}(\mathrm{NO})\right]\left[\mathrm{AI}\left(\mathrm{OR}^{\mathrm{F}}\right)_{4}\right]$ (3). A double-Schlenk flask was equipped inside the glove box with $\mathrm{Cr}(\mathrm{CO})_{6}\left(51 \mathrm{mg}, 0.232 \mathrm{mmol}, 1\right.$ eq.) and $\mathrm{NO}\left[\mathrm{Al}\left(\mathrm{OR}^{\mathrm{F}}\right)_{4}\right]$ (228 mg, $0.229 \mathrm{mmol}, 1$ eq.). Then, $\mathrm{CH}_{2} \mathrm{Cl}_{2}(\sim 3 \mathrm{~mL})$ was added at r.t. to the reaction mixture and the closed vessel was stirred for 14 days at r.t. After drying in vacuo, 3 yielded as an orange solid $(250 \mathrm{mg}, 0.210 \mathrm{mmol}, 92 \%)$. Orange single crystals were obtained by slow vapor diffusion of $n$-pentane in a solution of $\mathbf{3}$ in $o$ DFB at r.t. FTIR (ZnSe, ATR): $\tilde{v} / \mathrm{cm}^{-1}$ (intensity) = 2184 (vw), 2164 (vvw), 2127 (vvw), 2108 (ms), 2074 (vvw), $1841(\mathrm{mw}), 1821$ (vvw, trace of unknown impurity), $1353(\mathrm{vw}), 1299$ (mw), 1273 (ms), 1251 (ms), 1239 (ms), 1210 (vvs), 1162 (mw), 1140 (vw), 971 (vvs), 866 (vvw), 832 (vw), 756 (vvw), 727 (vs), 657 (w), 640 (vw), 571 (vvw), 561 (vw) (Supplementary Figure 46). FT Raman (100 scans, $\left.500 \mathrm{~mW}, 4 \mathrm{~cm}^{-1}\right): \tilde{v} / \mathrm{cm}^{-1}$ (intensity) $=2185(\mathrm{~m}), 2175(\mathrm{vw}), 2164(\mathrm{~m}), 2127(\mathrm{vvs}), 2112(\mathrm{vw}), 2076$ (vvw), 1843 (vvw), 1304 (vvw), 1275 (vvw), 977 (vvw), 797 (vw), 747 (vw), 640 (vw), 562 (vvw), 539 (vvw), 487 (vvw), 369 (vvw), $332(\mathrm{vw}), 290$ (vvw), 234 (vvw) (Supplementary Figure 47). ${ }^{1} \mathrm{H}$ NMR (300.18 MHz, oDFB, $298 \mathrm{~K}$ ): only solvent signals; ${ }^{13} \mathrm{C}\left\{{ }^{1} \mathrm{H}\right\} \mathrm{NMR}$ $(100.62 \mathrm{MHz}, o \mathrm{DFB}, 298 \mathrm{~K}): \delta / \mathrm{ppm}=201.9\left(\mathrm{~s}, 4 \mathrm{C}_{\text {equatorial }} \mathrm{Cr}(\mathrm{CO})_{5}(\mathrm{NO})\right), 187.3$ $\left(\mathrm{s}, 1 \mathrm{C}_{\text {axial }}, \mathrm{Cr}(\mathrm{CO})_{5}(\mathrm{NO})\right), 121.7\left(\mathrm{q},{ }^{1} J(\mathrm{C}, \mathrm{F})=293 \mathrm{~Hz}, 12 \mathrm{C}, \mathrm{CF}_{3}\right.$, in part overlapped by solvent signals), $79.5\left(\mathrm{~m}, 4 \mathrm{C}, 4 \times \mathrm{C}\left(\mathrm{CF}_{3}\right)_{3}\right) ;{ }^{14} \mathrm{~N}$ NMR $(21.69 \mathrm{MHz}, o \mathrm{DFB}, 298 \mathrm{~K})$ $\delta / \mathrm{ppm}=17$ (br. s, $\left.1 \mathrm{~N}, \mathrm{Cr}(\mathrm{CO})_{5}(\mathrm{NO})\right) ;{ }^{19} \mathrm{~F}$ NMR $(376.54 \mathrm{MHz}, o \mathrm{DFB}, 298 \mathrm{~K}):$ $\delta / \mathrm{ppm}=-75.3\left(\mathrm{~s}, 36 \mathrm{~F}, 4 \times \mathrm{C}\left(\mathrm{CF}_{3}\right)_{3} ;{ }^{27} \mathrm{Al} \mathrm{NMR}(78.22 \mathrm{MHz}, o \mathrm{DFB}, 298 \mathrm{~K}): \delta / \mathrm{ppm}=\right.$ $35.0\left(\mathrm{~s}, 1 \mathrm{Al}, \mathrm{Al}\left(\mathrm{OR}^{\mathrm{F}}\right)_{4}\right)$ (Supplementary Figures 17-21).

\section{Data availability}

Atomic coordinates and structure factors for the crystal structure of 1-4 are deposited at the Cambridge Crystallographic Data Centre (CCDC) under the accession codes 1844666 (compound 2), 1844667 (1), 1844668 (3), 1844669 (4), 1886541 (NO disorder model for 3), and 1886542 (NO disorder model for 4); copies of the data can be obtained free of charge from www.ccdc.cam.ac.uk/ data_request/cif. All the other data that support the findings of this study are available within Supplementary Information files, and are available from the corresponding authors on reasonable request.

Received: 14 August 2018 Accepted: 16 January 2019 Published online: 07 February 2019

\section{References}

1. Mond, L., Langer, C. \& Quincke, F. L. Action of carbon monoxide on nickel. J Chem. Soc. Trans. 57, 749-753 (1890).

2. Motterlini, R. \& Otterbein, L. E. The therapeutic potential of carbon monoxide. Nat. Rev. Drug Discov. 9, 728-743 (2010).

3. Beck, W. \& Suenkel, K. Metal complexes of weakly coordinating anions. Precursors of strong cationic organometallic Lewis acids. Chem. Rev. 88, 1405-1421 (1988)

4. Dyson, P. J. Catalysis by low oxidation state transition metal (carbonyl) clusters. Coord. Chem. Rev. 248, 2443-2458 (2004).

5. Waibel, R. et al. Stable one-step technetium-99m labeling of His-tagged recombinant proteins with a novel Tc(I)-carbonyl complex. Nat. Biotechnol. 17, 897-901 (1999)

6. Ishio, M., Terashima, T., Ouchi, M. \& Sawamoto, M. Carbonyl-phosphine hetero-ligated half-metallocene iron(II) catalysts for living radical polymerization. Concomitant activity and stability. Polym. J. 42, 17-24 (2010).

7. Mingos, D. M. P., Crabtree, R. H. \& Parkin, G. Comprehensive Organometallic Chemistry III (Elsevier, Oxford, 2007).

8. Ellis, J. E. Metal carbonyl anions. From $\left[\mathrm{Fe}(\mathrm{CO})_{4}\right]^{2-}$ to $\left[\mathrm{Hf}(\mathrm{CO})_{6}\right]^{2-}$ and beyond ${ }^{\dagger}$. Organometallics 22, 3322-3338 (2003).

9. Ragaini, F. et al. Radical processes in the reduction of nitrobenzene promoted by iron carbonyl clusters. X-ray crystal structures of $\left[\mathrm{Fe}_{3}(\mathrm{CO})_{9}\left(\mu_{3}-\mathrm{NPh}\right)\right]^{2-}$, $\left[\mathrm{HFe}_{3}(\mathrm{CO})_{9}\left(\mu_{3}-\mathrm{NPh}\right)\right]^{-}$, and the radical anion $\left[\mathrm{Fe}_{3}(\mathrm{CO})_{11}\right]^{\bullet-}$. Organometallics 14, 387-400 (1995). 
10. Fischer, E. O., Fichtel, K. \& Öfele, K. Über Cyclopentadienyl-metalltetracarbonyl-Kationen des Molybdän (II) und Wolfram (II)und ein Mangan (I)-hexacarbonyl-Kation. Chem. Ber. 95, 249-252 (1962).

11. Adelhelm, M., Bacher, W., Höhn, E. G. \& Jacob, E. Dicarbonylgold(I)hexafluorouranat(VI), $\left[\mathrm{Au}(\mathrm{CO})_{2}\right]\left[\mathrm{UF}_{6}\right]$. Chem. Ber. 124, 1559-1561 (1991).

12. Willner, $\mathrm{H}$. et al. Bis(carbonyl)gold(I) undecafluorodiantimonate(V), $[\mathrm{Au}$ $\left.(\mathrm{CO})_{2}\right]\left[\mathrm{Sb}_{2} \mathrm{~F}_{11}\right]$. Synthesis, vibrational, and carbon-13 NMR study and the molecular structure of bis(acetonitrile)gold(I) hexafluoroantimonate(V), [Au $\left.\left(\mathrm{NCCH}_{3}\right)_{2}\right]\left[\mathrm{SbF}_{6}\right]$. J. Am. Chem. Soc. 114, 8972-8980 (1992).

13. Willner, H. \& Aubke, F. Reaction of carbon monoxide in the super acid $\mathrm{HSO}_{3} \mathrm{~F}-\mathrm{Au}\left(\mathrm{SO}_{3} \mathrm{~F}\right)_{3}$, and the gold(I)bis(carbonyl)cation $\left[\mathrm{Au}(\mathrm{CO})_{2}\right]^{+}$. Isolation and characterization of gold(I) carbonyl fluorosulfate, $\mathrm{Au}(\mathrm{CO}) \mathrm{SO}_{3} \mathrm{~F}$. Inorg. Chem. 29, 2195-2200 (1990).

14. Bley, B., Willner, H. \& Aubke, F. Synthesis and spectroscopic characterization of hexakis(carbonyl)iron(II) undecafluorodiantimonate(V), $\left[\mathrm{Fe}(\mathrm{CO})_{6}\right]$ $\left[\mathrm{Sb}_{2} \mathrm{~F}_{11}\right]_{2}$. Inorg. Chem. 36, 158-160 (1997).

15. Bernhardt, E., Finze, M., Willner, H., Lehmann, C. W. \& Aubke, F. Co $(\mathrm{CO})_{5}\left(\mathrm{CF}_{3}\right)_{3} \mathrm{BF}$. A stable salt of a homoleptic trigonal-bipyramidal metalcarbonyl cation. Angew. Chem. Int. Ed. 42, 2077-2079 (2003).

16. Willner, H. et al. Superelectrophilic tetrakis(carbonyl)palladium(II)- and -platinum(II) undecafluorodiantimonate(V), $\left[\mathrm{Pd}(\mathrm{CO})_{4}\right]\left[\mathrm{Sb}_{2} \mathrm{~F}_{11}\right]_{2}$ and $[\mathrm{Pt}$ $\left.(\mathrm{CO})_{4}\right]\left[\mathrm{Sb}_{2} \mathrm{~F}_{11}\right]_{2}$. Syntheses, physical and spectroscopic properties, their crystal, molecular, and extended structures, and density functional calculations: an experimental, computational, and comparative study. J. Am. Chem. Soc. 123, 588-602 (2001).

17. Bach, C. et al. Cationic iridium(III) carbonyl complexes. $\left[\operatorname{Ir}(\mathrm{CO})_{6}\right]^{3+}$ and $[\mathrm{Ir}$ $\left.(\mathrm{CO})_{5} \mathrm{Cl}\right]^{2+}$. Angew. Chem. Int. Ed. 35, 1974-1976 (1996).

18. Poli, R. Open-shell organometallics as a bridge between Werner-type and lowvalent organometallic complexes. The effect of the spin state on the stability, reactivity, and structure. Chem. Rev. 96, 2135-2204 (1996).

19. $\mathrm{Xu}, \mathrm{Q}$. Metal carbonyl cations. Generation, characterization and catalytic application. Coord. Chem. Rev. 231, 83-108 (2002).

20. Willner, H. \& Aubke, F. Homoleptic metal carbonyl cations of the electronrich metals. Their generation in superacid media together with their spectroscopic and structural characterization. Angew. Chem. Int. Ed. 36, 2402-2425 (1997).

21. Willner, H. \& Aubke, F. $\sigma$-Bonded metal carbonyl cations and their derivatives. syntheses and structural, spectroscopic, and bonding principles. Organometallics 22, 3612-3633 (2003).

22. Willner, H. \& Aubke, F. Predominantly sigma-bonded metal carbonyl cations (sigma-carbonyls). New synthetic, structural, and bonding concepts in metal carbonyl chemistry. Chem. Eur. J. 9, 1668-1676 (2003).

23. Xu, Q. et al. Hexacarbonyldiplatinum(I). Synthesis, spectroscopy, and density functional calculation of the first homoleptic, dinuclear platinum(I) carbonyl cation, $\left[\left\{\mathrm{Pt}(\mathrm{CO})_{3}\right\}_{2}\right]^{2+}$, formed in concentrated sulfuric acid. J. Am. Chem. Soc. 122, 6862-6870 (2000).

24. Geier, J., Willner, H., Lehmann, C. W. \& Aubke, F. Formation of hexacarbonylmanganese(I) salts, $\mathrm{Mn}(\mathrm{CO})_{6}{ }^{+} \mathrm{X}^{-}$, in anhydrous HF. Inorg. Chem. 46, 7210-7214 (2007)

25. Souma, Y., Iyoda, J. \& Sano, H. Formation and properties of Group 1B metal carbonyl cations. Inorg. Chem. 15, 968-970 (1976).

26. Ivanova, S. M. et al. Mono-, di-, tri-, and tetracarbonyls of copper(I), including the structures of $\mathrm{Cu}(\mathrm{CO})_{2}\left(1-\mathrm{Bn}-\mathrm{CB}_{11} \mathrm{~F}_{11}\right)$ and $\left[\mathrm{Cu}(\mathrm{CO})_{4}\right]\left[1-\mathrm{Et}-\mathrm{CB}_{11} \mathrm{~F}_{11}\right]$. Inorg. Chem. 38, 3756-3757 (1999).

27. Schaefer, J. et al. A systematic investigation of coinage metal carbonyl complexes stabilized by fluorinated alkoxy aluminates. Chem. Eur. J. 19, 12468-12485 (2013).

28. Gurzhiy, V. V. et al. Hexacarbonyl-technetium(I) perchlorate. Acta Crystallogr. E 64, 1145 (2008).

29. Hurlburt, P. K., Anderson, O. P. \& Strauss, S. H. $\mathrm{Ag}(\mathrm{CO}) \mathrm{B}\left(\mathrm{OTeF}_{5}\right)_{4}$. The first isolable silver carbonyl. J. Am. Chem. Soc. 113, 6277-6278 (1991).

30. Pickett, C. J. \& Pletcher, D. Electrochemical synthesis of simple metal carbonyl cations. J. Chem. Soc. Chem. Commun. 0, 660-661 (1974).

31. Sahami, S. \& Osteryoung, R. A. Electrochemical oxidation of some metal carbonyls in ambient temperature ionic liquids. Electrochim. Acta 30, 143-146 (1985).

32. Pickett, C. J. \& Pletcher, D. Anodic oxidation of metal carbonyls in trifluoroacetic acid; stabilities of some 17-electron cations. J. Chem. Soc Dalton Trans. 0, 636-638 (1976).

33. Bagchi, R. N., Bond, A. M., Colton, R., Luscombe, D. L. \& Moir, J. E. Electrochemical oxidation of [dibenzo-18-crown-6-K] $\left[\mathrm{Cr}(\mathrm{CO})_{5} \mathrm{~F}\right]$ and $\mathrm{Cr}$ $(\mathrm{CO})_{6}$. Characterization of $\left[\mathrm{Cr}(\mathrm{CO})_{6}\right]^{+}$and its substitution reactions with fluoride and trifluoroacetate. J. Am. Chem. Soc. 108, 3352-3358 (1986).

34. Das, P. R., Nishimura, T. \& Meisels, G. G. Fragmentation of energy-selected hexacarbonylchromium ion. J. Phys. Chem. 89, 2808-2812 (1985).

35. Khan, F. A., Clemmer, D. E., Schultz, R. H. \& Armentrout, P. B. Sequential bond energies of chromium carbonyls $\left(\mathrm{Cr}(\mathrm{CO})_{\mathrm{x}}{ }^{+}, \mathrm{x}=1-6\right)$. J. Phys. Chem. 97, 7978-7987 (1993).
36. Zhou, X., Cui, J., Li, Z. H., Wang, G. \& Zhou, M. Infrared photodissociation spectroscopic and theoretical study of homoleptic dinuclear chromium carbonyl cluster cations with a linear bridging carbonyl group. J. Phys. Chem. A 116, 12349-12356 (2012).

37. Connelly, N. G. \& Geiger, W. E. Chemical redox agents for organometallic chemistry. Chem. Rev. 96, 877-910 (1996).

38. Meier, S. C. et al. From an easily accessible pentacarbonylcobalt(I) salt to piano-stool cations $\left[(\text { arene }) \mathrm{Co}(\mathrm{CO})_{2}\right]^{+}$. Chem. Eur. J. 23, 14658-14664 (2017).

39. Wang, G., Ceylan, Y. S., Cundari, T. R. \& Dias, H. V. R. Heterobimetallic silver-iron complexes involving $\mathrm{Fe}(\mathrm{CO})_{5}$ ligands. J. Am. Chem. Soc. 139, 14292-14301 (2017)

40. Malinowski, P. J. \& Krossing, I. Ag[Fe(CO) $\left.)_{5}\right]_{2}{ }^{+}$. A bare silver complex with $\mathrm{Fe}$ $(\mathrm{CO})_{5}$ as a ligand. Angew. Chem. Int. Ed. 53, 13460-13462 (2014).

41. Hayton, T. W., Legzdins, P. \& Sharp, W. B. Coordination and organometallic chemistry of metal-NO complexes. Chem. Rev. 102, 935-992 (2002).

42. Bernhardt, E., Finze, M., Willner, H., Lehmann, C. W. \& Aubke, F. Salts of the cobalt(I) complexes $\left[\mathrm{Co}(\mathrm{CO})_{5}\right]^{+}$and $\left[\mathrm{Co}(\mathrm{CO})_{2}(\mathrm{NO})_{2}\right]^{+}$and the Lewis acid-base adduct $\left[\mathrm{Co}_{2}(\mathrm{CO})_{7} \mathrm{CO}-\mathrm{B}\left(\mathrm{CF}_{3}\right)_{3}\right]$. Chem. Eur. J. 12, 8276-8283 (2006).

43. Shi, Q. Z., Richmond, T. G., Trogler, W. C. \& Basolo, F. Mechanism of carbon monoxide substitution in metal carbonyl radicals. Vanadium hexacarbonyl and its phosphine-substituted derivatives. J. Am. Chem. Soc. 106, 71-76 (1984).

44. Evans, D. F. The determination of the paramagnetic susceptibility of substances in solution by nuclear magnetic resonance. J. Chem. Soc. $\mathbf{0}$, 2003-2005 (1959).

45. van Wüllen, C. Molecular structure and binding energies of monosubstituted hexacarbonyls of chromium, molybdenum, and tungsten. Relativistic density functional study. J. Comput. Chem. 18, 1985-1992 (1997).

46. Ehlers, A. W., Dapprich, S., Vyboishchikov, S. F. \& Frenking, G. Structure and bonding of the transition-metal carbonyl complexes $\mathrm{M}(\mathrm{CO})_{5} \mathrm{~L}(\mathrm{M}=\mathrm{Cr}, \mathrm{Mo}$, $\mathrm{W})$ and $\mathrm{M}(\mathrm{CO})_{3} \mathrm{~L}\left(\mathrm{M}=\mathrm{Ni}, \mathrm{Pd}, \mathrm{Pt} ; \mathrm{L}=\mathrm{CO}, \mathrm{SiO}, \mathrm{CS}, \mathrm{N}_{2}, \mathrm{NO}^{+}, \mathrm{CN}^{-}, \mathrm{NC}^{-}\right.$, $\mathrm{HCCH}, \mathrm{CCH}_{2}, \mathrm{CH}_{2}, \mathrm{CF}_{2}, \mathrm{H}_{2}$ ). Organometallics 15, 105-117 (1996).

47. Masters, A. P., Parvez, M. \& Sorensen, T. S. Preparation of $\mathrm{Cr}_{2}(\mathrm{CO})_{8}(\mathrm{NO})_{2}$ and X-ray crystal structures of $\mathrm{Cr}_{2}(\mathrm{CO})_{8}(\mathrm{NO})_{2}$ and $\mathrm{Cr}_{2}(\mathrm{CO})_{9} \mathrm{NO}^{-}$. Stereochemical comparisons to $\mathrm{Cr}_{2}(\mathrm{CO})_{10}{ }^{2-}$. Can. J. Chem. 69, 2136-2141 (1991).

48. Sorensen, T. S., Sun, F. \& McDonald, R. Crystal structure of $[\mathrm{PPN}]^{+}[\mathrm{Cr}$ $(\mathrm{CO})_{4} \mathrm{NO}^{-}$. calculations and comparisons of $\mathrm{Cr}(\mathrm{CO})_{4} \mathrm{NO}^{-}$with $\mathrm{Mn}(\mathrm{CO})_{5}{ }^{-}$. Organometallics 20, 3613-3616 (2001).

49. Mantell, D. R. \& Gladfelter, W. L. Synthesis, characterization, and reactivity of $\mathrm{PPN}\left[\mathrm{Cr}(\mathrm{CO})_{4}(\mathrm{NO})\right]$. J. Organomet. Chem. 347, 333-342 (1988).

50. Breeze, P. A., Burdett, J. K. \& Turner, J. J. Charged carbonyls in matrices. Infrared structural characterization of tricarbonylnickel(1-), pentacarbonylchromium(1-), and tetracarbonyliron(1-). Inorg. Chem. 20, 3369-3378 (1981)

51. Bernhardt, E. et al. $D_{3 d}$ ground-state structure of $\mathrm{V}(\mathrm{CO})_{6}$. A combined matrix isolation and ab initio study of the Jahn-Teller effect. J. Phys. Chem. A 107, 859-868 (2003)

52. Fjare, K. L. \& Ellis, J. E. Synthesis, characterization, and chemistry of pentacarbonylnitrosylvanadium, $\mathrm{V}(\mathrm{CO})_{5} \mathrm{NO}$, a remarkably reactive relative of hexacarbonylchromium. J. Am. Chem. Soc. 105, 2303-2307 (1983).

53. Deringer, V. L., Wang, A., George, J., Dronskowski, R. \& Englert, U. Anisotropic thermal motion in transition-metal carbonyls from experiments and ab initio theory. Dalton. Trans. 45, 13680-13685 (2016).

54. Bellard, S., Rubinson, K. A. \& Sheldrick, G. M. Crystal and molecular structure of vanadium hexacarbonyl. Acta Crystallogr. B 35, 271-274 (1979).

55. Mohr, P. J., Newell, D. B. \& Taylor, B. N. CODATA recommended values of the fundamental physical constants. 2014. Rev. Mod. Phys. 88, 337 (2016).

56. Cummings, D. A., McMaster, J., Rieger, A. L. \& Rieger, P. H. EPR spectroscopic and theoretical study of chromium(I) carbonyl phosphine and phosphonite complexes. Organometallics 16, 4362-4368 (1997).

57. Sando, G. M. \& Spears, K. G. Density functional theory studies of the $\mathrm{Co}(\mathrm{Cp})_{2} \mid$ $\mathrm{V}(\mathrm{CO})_{6}$ radical-pair system. J. Phys. Chem. A 108, 1290-1297 (2004).

58. Bihlmeier, A., Gonsior, M., Raabe, I., Trapp, N. \& Krossing, I. From weakly coordinating to non-coordinating anions? A simple preparation of the silver salt of the least coordinating anion and its application to determine the ground state structure of the $\mathrm{Ag}\left(\eta^{2}-\mathrm{P}_{4}\right)_{2}{ }^{+}$cation. Chemistry 10, 5041-5051 (2004).

59. Riddlestone, I. M., Kraft, A., Schaefer, J. \& Krossing, I. Taming the cationic beast. Novel developments in the synthesis and application of weakly coordinating anions. Angew. Chem. Int. Ed.57, 13982-14024 (2017).

\section{Acknowledgements}

The authors would like to thank Dr. Thilo Ludwig for powder-XRD measurements, Dr. Harald Scherer for NMR measurements and the Bruker BioSpin GmbH for conducting 
low temperature EPR measurements. J.B. gratefully acknowledges financial support by the LGFG Graduate Funding. W.F. gratefully acknowledges the Carl-Zeiss-Stiftung for financial and the Studienstiftung des Deutschen Volkes e.V. for general support. This article is dedicated to Prof. Dr. Hansjörg Grützmacher on occasion of his 60th birthday.

\section{Author contributions}

I.K. supervised the project. J.B. designed and performed the experiments and all characterization but EPR measurements. D.H. carried out the general quantum mechanical calculations. M.D. did the Rietveld-refinement of the pXRD data, F.B. supervised the EPR measurements and respective EPR calculations carried out by W.F. All authors contributed to the discussion of the results and preparation of the manuscript.

\section{Additional information}

Supplementary Information accompanies this paper at https://doi.org/10.1038/s41467019-08517-2.

Competing interests: The authors declare no competing interests.

Reprints and permission information is available online at http://npg.nature.com/ reprintsandpermissions/
Journal peer review information: Nature Communications thanks the anonymous reviewers for their contributions to the peer review of this work. Peer reviewer reports are available.

Publisher's note: Springer Nature remains neutral with regard to jurisdictional claims in published maps and institutional affiliations.

cc (i) Open Access This article is licensed under a Creative Commons Attribution 4.0 International License, which permits use, sharing, adaptation, distribution and reproduction in any medium or format, as long as you give appropriate credit to the original author(s) and the source, provide a link to the Creative Commons license, and indicate if changes were made. The images or other third party material in this article are included in the article's Creative Commons license, unless indicated otherwise in a credit line to the material. If material is not included in the article's Creative Commons license and your intended use is not permitted by statutory regulation or exceeds the permitted use, you will need to obtain permission directly from the copyright holder. To view a copy of this license, visit http://creativecommons.org/ licenses/by/4.0/.

(C) The Author(s) 2019 